\title{
'SeXX' matters: In the myocardium of patients with type 1 diabetes
}

\author{
Deana Mikhalkova, MD, ${ }^{\mathrm{a}}$ Janet B. McGill, MD, FAHA, ${ }^{\mathrm{b}}$ and Linda R. Peterson, \\ MD, FAHA ${ }^{\text {a }}$ \\ ${ }^{a}$ The Cardiovascular Division of the Department of Medicine of Washington University School of \\ Medicine, Saint Louis, MO \\ ${ }^{b}$ The Endocrine Division of the Department of Medicine of Washington University School of \\ Medicine, Saint Louis, MO
}

Received Mar 9, 2016; accepted Mar 10, 2016

doi:10.1007/s12350-016-0507-2

\section{See related article, pp. 960-969}

Hepburn: "What I said was true, there's no difference between the sexes. Men, women, the same." Tracy: "They are?" Hepburn: "Well, maybe there is a difference, but it's a little difference." Tracy: "Well, you know as the French say?' Hepburn: "What do they say?" Tracy: "Vive la difference!" Hepburn: "Which means?" Tracy: "Which means hurrah for that little difference."'-from Adam's Rib

It is widely known that patients with type 1 diabetes (T1DM) have an increased risk of developing left ventricular (LV) dysfunction, ${ }^{1-3}$ and a fourfold increased risk of heart failure (HF). ${ }^{4}$ However, a recent study has shown that there are also sex-related differences in the risk of HF development in patients with T1DM-with women having a higher risk of HF than men. ${ }^{4}$ Given the inextricable links between myocardial blood flow, oxygen consumption, efficiency, and function, it is vital to better understand the effects of sex and T1DM on these parameters. Sympathetic dysfunction and subclinical cardiovascular (CV) autonomic neuropathy in T1DM have also been implicated in abnormalities of myocardial blood flow and even left ventricular diastolic dysfunction. ${ }^{1}$ Sex-related differences in risk of disease,

Reprint requests: Linda R. Peterson, MD, FAHA, The Cardiovascular Division, Department of Medicine of Washington University School of Medicine, Campus Box 8086, 660 S. Euclid Ave, St. Louis, MO 63110; lpeterso@dom.wustl.edu

J Nucl Cardiol 2016;23:970-2.

$1071-3581 / \$ 34.00$

Copyright (c) 2016 American Society of Nuclear Cardiology. myocardial blood flow, oxygen consumption, efficiency, and sympathetic input are important to define because they could lead to more targeted development and testing of novel diabetes therapies aimed at blood flow and metabolism and the nervous system. And in this evolving era of personalized medicine, an effective and targeted approach-one that embraces the proven clinical differences between the sexes-could have an immediate, positive impact on patients.

In this issue of the Journal of Nuclear Cardiology, the major novel findings by Duvoney et al included several specific and significant sex-related differences in patients with T1DM. ${ }^{5}$ The women with T1DM had higher myocardial blood flow, oxygen consumption, $\left[{ }^{11} \mathrm{C}\right]$ meta-hydroxyephedrine $\left(\left[{ }^{11} \mathrm{C}\right] \mathrm{mHED}\right)$ retention index, and lower efficiency than their male counterparts. Sex-related differences in myocardial flow, oxygen consumption, efficiency, and metabolism have also been observed in prior PET-related studies in healthy and obese subjects, patients with type 2 diabetes, and patients with nonischemic cardiomyopathy. ${ }^{6-8}$ In several studies of healthy and obese individuals, women tended to have higher myocardial blood flow than men. ${ }^{7-9}$ This is similar to the results from the current study by Duvernoy et al. ${ }^{5}$ Myocardial blood flow was also higher in women with type 2 diabetes compared with men with the same disease. This is consistent with prior literature, which has been fairly consistent in demonstrating that oxygen consumption is generally higher in womennormal, obese, and with type 2 diabetes mellitus, than in comparable groups of men. ${ }^{10}$ Efficiency was also lower in lean and obese women than in their male counterparts. ${ }^{8}$ Table 1 shows a summary of prior PET studies comparing sex-related differences in healthy and obese subjects, patients with type 2 diabetes, and patients with nonischemic HF. ${ }^{6}$ Evaluating whether there are sex-related effects on myocardial blood flow, oxygen 
Table 1. Sex-related differences in myocardial blood flow, oxygen consumption, and efficiency

\begin{tabular}{|c|c|c|c|c|c|}
\hline & $\begin{array}{l}\text { Number } \\
\text { of men }\end{array}$ & $\begin{array}{c}\text { Number of } \\
\text { women }\end{array}$ & $\begin{array}{c}\text { Resting } \\
\text { myocardial blood } \\
\text { flow }\end{array}$ & $\begin{array}{l}\text { Myocardial oxygen } \\
\text { consumption }\end{array}$ & Efficiency \\
\hline Peterson et $\mathrm{al}^{7}$ & $\begin{array}{l}\text { Healthy } \\
12\end{array}$ & $\begin{array}{l}\text { Healthy } \\
13\end{array}$ & $\begin{array}{l}\text { Women }>\text { men } \\
\text { (trend, } P .16 \text { ) }\end{array}$ & $\begin{array}{l}\text { Women }>\text { men } \\
(P<.005)\end{array}$ & $\begin{array}{l}\text { Women }<\text { men } \\
\text { (Trend, } P \text {.07) }\end{array}$ \\
\hline Soto et $\mathrm{al}^{9}$ & $\begin{array}{l}\text { Healthy } \\
60-75 \text { yo } \\
6\end{array}$ & $\begin{array}{l}\text { Healthy } \\
60-75 \text { yo } \\
6\end{array}$ & $\begin{array}{l}\text { Women }>\text { men } \\
\text { (trend, } P \text {.07) }\end{array}$ & & \\
\hline Lyons et al ${ }^{10}$ & $\begin{array}{l}\text { T2DM } \\
46\end{array}$ & $\begin{array}{l}\text { T2DM } \\
43\end{array}$ & $\begin{array}{l}\text { Women }>\text { men } \\
(P<.0001)\end{array}$ & $\begin{array}{l}\text { Women }>\text { men } \\
(P<.0001)\end{array}$ & \\
\hline Peterson et $\mathrm{al}^{8}$ & $\begin{array}{l}\text { Obesity } \\
30\end{array}$ & $\begin{array}{l}\text { Obesity } \\
56\end{array}$ & $\begin{array}{l}\text { Women }>\text { men } \\
(P<.0001)\end{array}$ & $\begin{array}{l}\text { Women }>\text { men } \\
(P<.0001)\end{array}$ & $\begin{array}{l}\text { Women }<\text { men } \\
(P<.05)\end{array}$ \\
\hline $\begin{array}{l}\text { Kadkhodayan, } \\
\text { Lin et } \mathrm{al}^{11}\end{array}$ & $\begin{array}{l}\text { Heart failure } \\
9\end{array}$ & $\begin{array}{l}\text { Heart failure } \\
10\end{array}$ & $\begin{array}{l}\text { Women }>\text { men } \\
(P<.005)\end{array}$ & & \\
\hline
\end{tabular}

consumption, and efficiency in each of these subject groups (normal, obese, patients with diabetes, and those with heart failure) is necessary because there are known differences in substrate metabolism (e.g., fat vs glucose) due to the various conditions/diseases, which can affect oxygen consumption and oxygen efficiency. ${ }^{6}$ Moreover, there are different hormonal, hemodynamic, and metabolic milieux associated with these various conditions/ diseases, so one cannot assume that the sex-related differences that are seen in healthy subjects automatically extrapolate to patients with T1DM. While it is tempting to attribute all of these myocardial sex-related differences to sex hormones, data suggest that not all of the differences are hormone driven. For example, there were no differences in resting (or adenosine-enhanced) myocardial blood flow in postmenopausal women who received estrogen replacement therapy in a placebocontrolled, double-blind study. ${ }^{11}$ However, estrogen does increase uncoupling protein expression in muscle of animal models, suggesting that estrogen may increase oxygen consumption and decrease efficiency in the heart. ${ }^{12}$ The sex-related difference in higher $\left[{ }^{11} \mathrm{C}\right] \mathrm{mHED}$ retention index in patients with T1DM is also a novel finding of the study by Duvernoy et al. Whether this relates to the higher risk of HF in women with T1DM will require further longitudinal study.

Duvernoy et al also compared myocardial blood flow, oxygen consumption, efficiency, and a measure of sympathetic function between all the patients with T1DM (men and women) and normal controls. ${ }^{5}$ The current study used $\left[{ }^{11} \mathrm{C}\right] \mathrm{mHED}$ in conjunction with PET imaging for evaluation of cardiac sympathetic function. $\left[{ }^{11} \mathrm{C}\right] \mathrm{mHED}$ is a synthetic 'false transmitter' analog of norepinephrine. It is taken up by and retained in the sympathetic nerve terminals in the myocardium and can be imaged using PET. An advantage of this tracer is that the images are less effected by non-neuronal uptake, and it has better spatial resolution ${ }^{13}$ than another commonly used tracer, $\left[{ }^{123} \mathrm{I}\right]$ meta-iodobenzylguianidine (MIBG) ${ }^{14}$ Interestingly, the researchers found no difference in myocardial sympathetic activity, blood flow, LV function, or efficiency between patients with T1DM and controls, but there was a trend toward the former having higher oxygen consumption. These findings are partially consistent with a previous study by Herrero et al, which showed no differences in myocardial blood flow between patients with T1DM and controls but higher myocardial oxygen consumption $\left(\mathrm{MVO}_{2}\right)$ in patients, though efficiency in that study $\left(\mathrm{MVO}_{2} /\right.$ rate-pressure product) was not different between the groups. ${ }^{15}$ Differences in patient characteristics between the 2 studies and the relatively small numbers of subjects in these expensive PET studies may have contributed to the slight difference between the studies' findings. The lack of a difference in sympathetic activity in the current study is a bit unexpected given the patients' higher resting heart rate compared to controls. Other studies have also demonstrated higher resting heart rates ${ }^{16}$ and lower heart rate variability in patients with T1DM compared with controls. ${ }^{17}$ However, heart rate and heart rate variability are influenced by many different inputs including parasympathetic tone, hormones, temperature, and levels of various ions and molecules. The lack of a difference in the norepinephrine analog tracer in the myocardium between the normal subjects and the patients with T1DM may simply mean that sympathetic stimuli/hormones are not the main influence on the heart rate difference between the 2 groups. Thus, one of the other factors listed above may be more influential than sympathetic drive on the resting heart rate in the patients 
with T1DM. Alternatively, the lack of a difference between the 2 groups' $\left[{ }^{11} \mathrm{C}\right] \mathrm{mHED}$ retention index may also result from the relatively small number of subjects, though this is less likely based on the authors' power calculations. The authors also found that among those with T1DM, a higher Kmono was directly related to a higher $\left[{ }^{11} \mathrm{C}\right] \mathrm{mHED}$ retention index. This is not too surprising since increased sympathetic drive and oxygen consumption are linked. For example, patients with T1DM (and normal controls) who are treated with dobutamine increase myocardial oxygen consumption. ${ }^{18}$ Interestingly, there was a stronger correlation between the $\left[{ }^{11} \mathrm{C}\right] \mathrm{mHED}$ retention index and oxygen consumption among the women with T1DM than among the men, another sex-related difference.

Identifying the myocardial differences between the sexes in T1DM and the differences between those with T1DM and healthy controls is an important task. The next step is to put this new knowledge to work by embracing the importance of these differences when developing and testing novel therapies for the diabetic heart. "Hurrah for that little difference!"

\section{Acknowledgments}

The authors thank Kristin O'Callaghan for her editorial assistance and are grateful for her expertise.

\section{References}

1. Pop-Busui R, Kirkwood I, Schmid H, Marinescu V, Schroeder J, Larkin D, et al. Sympathetic dysfunction in type 1 diabetes: Association with impaired myocardial blood flow reserve and diastolic dysfunction. J Am Coll Cardiol. 2004;44:2368-74.

2. Pop-Busui R, Cleary PA, Braffett BH, Martin CL, Herman WH, Low PA, et al. Association between cardiovascular autonomic neuropathy and left ventricular dysfunction: DCCT/EDIC study (diabetes control and complications trial/epidemiology of diabetes interventions and complications). J Am Coll Cardiol. 2013;61:447-54

3. Spallone V, Ziegler D, Freeman R, Bernardi L, Frontoni S, PopBusui R, et al. Cardiovascular autonomic neuropathy in diabetes: Clinical impact, assessment, diagnosis, and management. Diabetes Metab Res Rev. 2011;27:639-53.

4. Rosengren A, Vestberg D, Svensson AM, Kosiborod M, Clements M, Rawshani A, et al. Long-term excess risk of heart failure in people with type 1 diabetes: A prospective case-control study. Lancet Diabetes Endocrinol 2015;3:876-85.
5. Duvernoy C, Raffel D, Swanson S, Jaiswal M, Mueller G, Ibrahim E-S, et al. Left ventricular metabolism, function and sympathetic innervation in men and women with type 1 diabetes. J Nucl Cardiol 2016. doi:10.1007/s12350-016-0434-2.

6. Kadkhodayan A, Lin CH, Coggan AR, Kisrieva-Ware Z, Schechtman K, Novak E, et al. Sex affects myocardial blood flow and fatty acid substrate metabolism in humans with nonischemic heart failure. J Nucl Cardiol 2016. doi:10.1007/s12350016-0467-6.

7. Peterson LR, Soto PF, Herrero P, Schechtman KB, Dence C, Gropler RJ. Sex differences in myocardial oxygen and glucose metabolism. J Nucl Cardiol 2007;14:573-81.

8. Peterson LR, Soto PF, Herrero P, Mohammed BS, Avidan MS, Schechtman $\mathrm{KB}$, et al. Impact of gender on the myocardial metabolic response to obesity. JACC Cardiovasc Imaging 2008;1:424-33.

9. Soto PF, Herrero P, Schechtman KB, Waggoner AD, Baumstark JM, Ehsani AA, et al. Exercise training impacts the myocardial metabolism of older individuals in a gender-specific manner. Am J Physiol Heart Circ Physiol 2008;295:H842-50.

10. Lyons MR, Peterson LR, McGill JB, Herrero P, Coggan AR, Saeed IM, et al. Impact of sex on the heart's metabolic and functional responses to diabetic therapies. Am J Physiol Heart Circ Physiol 2013;305:H1584-91.

11. Peterson LR, Eyster D, Dávila-Román VG, Stephens AL, Schechtman KB, Herrero $P$, et al. Short-term oral estrogen replacement therapy does not augment endothelium-independent myocardial perfusion in postmenopausal women. Am Heart $\mathbf{J}$ 2001;142:641-7.

12. Pedersen SB, Bruun JM, Kristensen K, Richelsen B. Regulation of UCP1, UCP2, and UCP3 mRNA expression in brown adipose tissue, white adipose tissue, and skeletal muscle in rats by estrogen. Biochem Biophys Res Commun 2001;288:191-7.

13. Mann DL, Felker GM. Heart failure: A companion to Braunwald's heart disease, 3e: Saunders; 2015, p. 784.

14. Melon PG, Nguyen N, DeGrado TR, Mangner TJ, Wieland DM, Schwaiger M. Imaging of cardiac neuronal function after cocaine exposure using carbon-11 hydroxyephedrine and positron emission tomography. J Am Coll Cardiol 1994;23:1693-9.

15. Herrero P, Peterson LR, McGill JB, Matthew S, Lesniak D, Dence $\mathrm{C}$, et al. Increased myocardial fatty acid metabolism in patients with type 1 diabetes mellitus. J Am Coll Cardiol 2006;47:598-604.

16. Peterson LR, Waggoner AD, Fuentes L, Schechtman KB, McGill $\mathrm{JB}$, Gropler RJ, et al. Alterations in left ventricular structure and function in type-1 diabetics: A focus on left atrial contribution to function. J Am Soc Echocardiogr 2006;19:749-55.

17. Jaiswal M, Urbina EM, Wadwa RP, Talton JW, D'Agostino RB, Hamman RF, et al. Reduced heart rate variability among youth with type 1 diabetes: The search CVD study. Diabetes Care 2013;36:157-62.

18. Herrero P, McGill J, Lesniak DS, Dence CS, Scott SW, KisrievaWare Z, et al. PET detection of the impact of dobutamine on myocardial glucose metabolism in women with type 1 diabetes mellitus. J Nucl Cardiol 2008;15:791-9. 